\title{
NOTE \\ EXPERIMENTAL INFECTION OF MICE WITH TAIL-LESS SCHISTOSOMA JAPONICUM CERCARIAE
}

Sugiura and Ota (1954) reported that hamsters did not become infected when experimentally exposed to tail-less Schistosoma japonicum cercariae (see also Ritchie, 1955). It was implied that through the physical loss of their tails, schistosome cercariae are not capable of infecting a definitive host. Because of the epidemiological significance of their experiment and the impressions which could be drawn from their observations, it is important to perform further studies employing different experimental procedures.

Cercariae obtained by crushing 20 Oncomelania nosophora snails harboring mature infections of $S$. japonicum were pooled and divided into two groups. One group was used as the controls (cercariae with tails), and the other, the test cercariae (tail-less). The test group was rendered tail-less by pouring actively swimming specimens into a plastic screw-top bottle which was dropped several times on a hard surface.

Forty (40) albino mice (SM strain) were divided into eight groups of five mice each (Groups I through VIII). Animals in Groups I through IV were individually exposed to 100 tail-less cercariae by allowing each mouse to wade in a $600 \mathrm{ml}$ beaker containing cercariae with water to a depth of 10 millimeters. Animals in Groups I, II, III and IV were exposed for 5, 10,20 and 30 minutes respectively. The method of exposing animal groups V through VIII was the same except that each mouse was individually exposed to 50 cercariae with tails. All of the animals were sacrificed 42 days after exposure and their worm burdens were determined and totaled by group. Results appear in Table 1.

It is apparent from the findings of this experiment that tail-less $S$. japonicum cercariae are capable of infecting a definitive host and that the rates of infection in animal groups exposed to both tailed and tail-less cercariae are significantly related to the length of time that the animals are exposed (Groups I-IV, $\mathrm{P} \approx 0$; and Groups V-VIII, $\mathrm{P} \approx 0$ ).

Table 1. Infection rates in mice experimentally exposed to tailed and tail-less Schistosoma japonicum cercariae

\begin{tabular}{|c|c|c|c|c|c|c|}
\hline \multirow{2}{*}{$\begin{array}{l}\text { Animal } \\
\text { group }\end{array}$} & \multirow{2}{*}{$\begin{array}{l}\text { No. of } \\
\text { animals }\end{array}$} & \multirow{2}{*}{$\begin{array}{c}\text { Cercarial } \\
\text { type }\end{array}$} & \multirow{2}{*}{$\begin{array}{l}\text { No. of } \\
\text { cercariae }\end{array}$} & \multirow{2}{*}{$\begin{array}{l}\text { Length of } \\
\text { exposure } \\
\text { (minutes) }\end{array}$} & \multicolumn{2}{|c|}{ No. of worms recovered } \\
\hline & & & & & Total & Per cent \\
\hline I & 5 & Tail-less & 100 & 5 & 7 & 1.4 \\
\hline II & 5 & do. & 100 & 10 & 42 & 8.4 \\
\hline III & 5 & do. & 100 & 20 & 53 & 10.6 \\
\hline IV & 5 & do. & 100 & 30 & 102 & 20.4 \\
\hline $\mathrm{V}$ & 5 & With tails & 50 & 5 & 24 & 9.6 \\
\hline $\mathrm{VI}$ & 5 & do. & 50 & 10 & 39 & 15.6 \\
\hline VII & 5 & do. & 50 & 20 & 71 & 28.4 \\
\hline VIII & 5 & do. & 50 & 30 & 68 & 27.2 \\
\hline
\end{tabular}


The results indicating the recovery of fewer worms from the animal groups exposed to tail-less cercariae when compared to those groups which were exposed to tailed cercariae are, in all instances, significant and was probably not by chance. (Groups I and V, $\mathrm{P}<0.0005$; Groups II and VI, $\mathrm{P}=0.003$; Groups III and VII, $\mathrm{P} \approx 0$; and Groups IV and VIII, $\mathrm{P}=0.04$ ).

The results obtained in the present study are not comparable with those of Sugiura and Ota (loc. cit.) since the experimental animals and methods of procedure differed. The authors' experiment was designed solely to determine whether or not tail-less cercariae are capable of infecting a definitive host.

Statistical evaluation of the data by First Lieutenant Harris H. Lloyd, MSC, Chief, Department of Biochemistry, 406th Medical Laboratory, is gratefully acknowledged.

\section{REFERENCES}

Ritchie, L. S. (1955): The biology and control of the amphibious snails that serve as intermediate hosts for Schistosoma japonicum. Am. J. Trop. Med. Hyg. 4, 426-441.

SUgIURA, S. AND OTA, S. (1954): On the kill of schistosome cerJariae. Japan. J. Parasitol. $3,48-49$ (abst.).

Department of Medical Zoology 406th Medical Laboratory

U.S. Army Medical Command, Japan

APO San Francisco 96343

Received: June 26th, 1965
JOHN W. MOOSE

JAMES E. WILLIAMS

SHOHEI YAMAGUCHI 